\title{
The Bluest Eye: A Tragedy of Oppression and Internalized Racism
}

\author{
Dr. Neelam Bhardwaj \\ Assistant Professor \\ S.C.D. Govt. College, Ludhiana
}

\begin{abstract}
The life of life of African-American women had been affected by racism, sexism and classicism. These so-called systems of social and psychological restrictions were put on the Africans living in that country when the coloured people were regarded as inferiors. As the blacks were relegated to a lower class by virtue of their race, women were related to a separate caste by virtue of their sex. In the same way, black women were also victimised not only on the basis of races and sex but they were also badly treated by class exploitations which was the greatest oppression of blacks in America. In this way, black women suffered from the double disadvantage of racial discrimination and gender bias. That black women survived and flourished under these conditions is surely a testament to the human spirit, but that is precisely the point. Black women, in the midst of both racism and sexism, did survive, and their ability to do was the glue that wrapped together black communities both during and after slavery. Hence, the hierarchy created by patriarchal society crumbles to a certain extent in Toni Morrison. She exhibits the woman's situation, emotion and realization which are scrutinized to observe the universality of female psyche. Toni Morrison's The Bluest Eye deals with the life of women, their activities and their victimization at the hands of male ones. They are not human beings but simply things to be used and this is why they are subhuman, exploited and tortured all their life. This paper is an insight to discuss the life of African-American women who are the victims of the prejudices everywhere in the society and in their own families.
\end{abstract}

Keywords: Exploitation, Racial Discrimination, Gender, Inequality, Oppression.

Black Women Writers have contributed significantly to unravel the urge for affirmation and identity in the African-American pantheon. The legacies begun by Phillis Wheatley and furthered by writers like Zora, Neale, Hurtson and Dorothy West led to the emergence of writers like Toni Morrison, Gloria Naylor, Toni Cade Bambara, Alice Walker, Ntozaka Shange, Audre Lorde and others. Toni Morrison exhorts:

I write for black women. We are not addressing the men, as some white female writers do. We are not attacking each other, as both black and white men do. Black women writers look at things in an unforgiving, loving way. They are writing to responses, rename, re-own (Nellie 64).

She is a well-known African-American woman writer of modern age who has won several literary awards. She is the most celebrated and the first African- American author ever to receive both the Pulitzer and the Nobel Prize for Literature. She is more widely read by a broader cross- section of the American reading public than any other black writer has ever been in this country. What distinguishes Morrison from other writers is the affirmative approach of her characters towards life.

Toni Morrison is very well known for her African-American identity. She tried to discover the complex life of the black slaves and other men and women who were living in a highly backward and neglected condition in America. They were not only hated by the white men and women of America but they were also treated in a manner worse than animals. She was much more concerned with the life and improvement of the black community. Once, she said these significant words in an interview with Salman Rushdie:

I am not sure what the word 'Negro' means, which is why I write books. What is black child/woman/friend/ mother? What is a black person? It seems to me that there are so many that inform blackness. One of the modern qualities of being an African-American is the flux, is the fluidity, the contradictions (Rushdie 36). 
The study of her novels clearly shows her exploration of the meaning of blackness, related to its meaning of black in America which is dominated by the white. She showed the difference between a black woman and white woman in the contemporary society of America. Her novels clearly show the record, the triumph and complexities of black life from the past slavery to the frustrating present. Her main purpose was writing from the point of view of a black female. She condemns the way the African- American looks at themselves through the white standard of beauty and culture. Modern means of communication- Radio, Press, T.V., and Cinema etc. have planted these symbols of beauty and culture deep into the psyche of modern man and women. Toni Morrison believes that people are not born with the tendency to hurt people; they are taught to do so when they are themselves hurt.

Morrison's first novel, The Bluest Eye, examines the tragic effects of imposing white, middle-class American ideals of beauty on the developing female identity of a young African American girl during the early 1940s. Inspired by a conversation Morrison once had with an elementary school classmate who wished for blue eyes, the novel poignantly shows the psychological devastation of a young black girl, Pecola Breedlove, who searches for love and acceptance in a world that denies and devalues people of her own race. As her mental state slowly unravels, Pecola hopelessly longs to possess the conventional American standards of feminine beauty - namely, white skin, blonde hair, and blue eyes-as presented to her by the popular icons and traditions of white culture. Written as a fragmented narrative from multiple perspectives and with significant typographical deviations, The Bluest Eye juxtaposes passages from the Dick-and-Jane grammar school primer with memories and stories of Pecola's life alternately told in retrospect by one of Pecola's now-grown childhood friends and by an omniscient narrator. Published in the midst of the Black Arts movement that flourished during the late 1960s and early 1970s, The Bluest Eye has attracted considerable attention from literary critics - though not to the same degree as Morrison's later works. With its sensitive portrait of African American female identity and its astute critique of the internalized racism bred by American cultural definitions of beauty, The Bluest Eye has been widely seen as a literary watershed, inspiring a proliferation of literature written by African- American women about their identity and experience as women of colour.

Let us now discuss what exactly it means by 'Racism'. Racism involves the belief in racial differences which acts as a justification for non-equal treatment of members of that race. The term is commonly used negatively. It is usually associated with race-based prejudice, violence, dislike, discrimination, or oppression; the term can also have varying and contested definitions. As a word, racism is an "-ism", a belief that can be described by a word ending in the suffix -ism, pertaining to race. The exact definition of racism is controversial both because there is little scholarly agreement about the meaning of the concept 'race', and because there is also little agreement about what does and doesn't constitute discrimination. Critics argue that the term is applied differentially, with a focus on such prejudices by whites and defining mere observations of racial differences as racism.

The Bluest Eye explores the tragedy of the oppression and internalized racism .This novel presents the story of two black families, Macteers and Breedlove. Both are poor African-American families, though Macteer is a little better placed who have migrated from Alabama and Georgia (South American States) via Kentucky to Lorain- Ohio, an industrial state, in search of job. The novel shows clearly the evil of racism through the African adolescent female - like Pecola. She, like other African girls, suffered from the evils of racism and sexism in America which was dominated by the white. Pecola was an eleven year old poor, ugly and black girl who longed to have blue eyes. She also hoped that then she would get that love which she desired to get and it would reduce her sufferings in the quarrelsome atmosphere in her parents' house. She was raped by her own father and beaten by her mother because they had been badly influenced by the vicious standards of the white world. She not only suffered as a black girl but also as an unprotected female. Morrison, who had sympathy for Pecola, was conscious of the neglect and exploitation of black African people by the white.

A perusal of the novel The Bluest Eye creates an impression that Toni Morrison intertwines the concerns of two main themes in her novel The Bluest Eye. She explores the tragedy of the oppression or violation of children, especially poor children and she explores a problem specific to groups targeted by racism, that of internalized racism. This is a kind of thinking produced when members of the targeted group, in this case African-Americans, begin to believe the stereotypes about themselves and imagine that European-Americans are superior in beauty, morality and intelligence. Morrison focuses on this problem of internalized racism as if affects children. The psychological mechanism of internalized racism hinges on the cycle of oppressions. 
The cycle of oppression is a complex phenomenon that affects all people who are touched by oppressive systems, whether they are assigned the role of oppressor or oppressed. The child is oppressed and because she is a child. She/he is unable to combat or resist her/his oppression. She/he is taught to react to injustice and hurts with different kinds of disempowered responses - silence, selfabuse, depression, and rage. When the child grows up in this oppressive system, her/his position often shifts and she/he assumes the role of the oppressor. This cycle is especially clear when seen in the oppression of children, but it is also visible in the oppression of groups of people based on their ethnic identity.

In The Bluest Eye, the oppressors of Pecola have themselves been hurt by oppressive adults and/or racist ideology. Morrison is very careful to point out that people are not born with the tendency to hurt other people; instead, they are taught to do so when they themselves are hurt. A perfect example of this phenomenon is Pauline, Mrs. Breedlove. She is rejected by the women in the Lorain community because she bears the marks of her colour and class too overtly. She wears the clothing of country people and speaks with a southern accent. Pauline responds by adopting the oppressor's discourse, particularly the discourse on physical beauty. Measured against it, Pauline is ugly and her white employers are beautiful and deserving of all her care and love. Pauline, thereby, accepts her assigned role on the hierarchy of colour, beauty and privilege. This role leaves her incapable of caring for her daughter or anyone in her family. According to its script, they do not deserve any of her care.

Pecola is born with this ideology of racialized beauty. She doesn't have a chance from the beginning. Her mother has placed all her care in her job and she has internalized the message that black is ugly and white is beautiful to such an extent that she sees Pecola as an ugly ball of black hair when she is born. She and Cholly seem to have given Pecola no love and nourishment. They are so preoccupied with their own war on each other that they never seem to notice the damage it is causing their daughter. Echoing the situation of the Breedloves is that of the MacTeers. Morrison constructs these two families as a sort of plot and subplot along the lines of Shakespeare's King Lear. The MacTeers do not have it as bad as the Breedloves do. While the parents seem to be quite embattled by poverty, they retain their allegiance to their home. Mr. MacTeer regards it as his steadfast duty to provide for his family and to ensure her daughters' upbringing in the accepted morality of their time. Neither parent has the time or the emotional energy to nurture their daughters. They treat Claudia and Frieda as pieces of furniture, which are inconvenient, but necessary to care for. Mrs. MacTeer treats them with rough care, but cares nonetheless. She dispenses punishment arbitrarily and too swiftly, not recognizing their physical or moral integrity. She stops short of abusing them for the mere sake of releasing her own pent up frustrations.

When Frieda is sexually molested by Mr. Henry, her parents believe her story and act on it swiftly, punishing Mr. Henry, and leaving Frieda to draw her own conclusions about what it meant. Mrs. MacTeer, unwittingly, foists on her daughters the ideology of white supremacy when she gives them white dolls, as Christmas gift, to love and cherish, but she never says directly that her daughters are ugly:

Adults, older girls, shops, magazines, newspapers, window sign - all the world had agreed that a blue-eyed, yellow-haired, pink-skinned doll was what every girl child treasured. 'Here,' they said, 'this is beautiful, and if you are on this day "worthy" you may have it (Morrison 20-21).

The MacTeer family seems to represent the mainstream African- American family in Lorain, Ohio at the time the novel was set. Most African-Americans were poor, and most attempted to make it by adopting the code of respectability. The poor treatment of children was the norm, but the violation of children's innocence was done ideologically more than physically. The Breedlove family represents all the faults of this African- American community writ large. In structuring her novel in this way, Morrison avoids the simplistic analysis which would simply regard the Breedloves as an unfortunate aberration. Instead, they are the logical extension of the norm.

Thus, Toni Morrrison dealt with the serious problem of racism and sexuality of the black Africans who were living in America. They were much neglected and exploited by the men and women of white- skin against the black-skinned people in that great country. She was perfectly aware of and deeply concerned about the conditions of over-poverty, suppression and exploitation of those Africans in America. In this way, she had clear consciousness of the inter-relationship of race, gender and class as Friere has argued, "Indeed, the interests of the oppressors lie in changing the consciousness of the oppressed, not the situation which oppress them... for the more the oppressed can be led to adapt to that situation, the more easily they can be dominated"(Friere47). 


\section{REFERENCES}

[1] Morrison, Toni. The Bluest Eye, New York: Rinehart and Winston, 1970. Print.

[2] Bump, Jerome. "Family Systems Therapy and Narrative." Reading the Family Dance: Family Systems Therapy and Literature Study. Ed. Womack Kenneth and John V Knapp. Newark: UP, 2003. Print.

[3] Morrison, Toni. "Home." The House That Race Built. Ed. Wahneema Lubiano. New York: Pantheon Books, 1997. Print.

[4] Ladner, Joyce, Tomorrow's Garden City, New York: Doubleday, 1971. Print.

[5] Russel, Sandi. "It's Ok to say Ok ", An Interview Essay: Critical Essays on Toni Morrison, Ed. Nelliey. Boston:Y. Mcka, 1988. Print.

[6] Paulo Friere, Pedagogy of the Oppressed. England: Pelican Books, 1972. Print.

\section{AUTHOR's BIOGRAPHY}

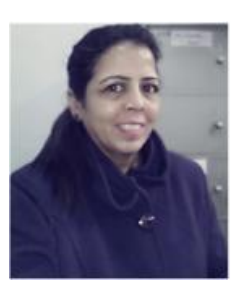

Dr. Neelam Bhardwaj is an Assistant Professor in the Post-Graduate Department of English, S.C.D. Govt. College, Ludhiana, Punjab which is affiliated with Panjab University, Chandigarh. She has presented a number of papers at various National and International Seminars and Conferences. She has also to her credit many research papers which are published in edited anthologies as well as International Journals of great repute. She is in the Editorial Board of two International Journals. Her areas of interest are Indian Writings in English, American Literature, World Literature, Gender Studies, Post-Colonial Writing, Diasporic Literature, and British Literature. 